\title{
Lime and phosphogypsum impacts on soil organic matter pools in a tropical Oxisol under long-term no-till conditions
}

\author{
Antonio C.A. Carmeis Filho ${ }^{\mathrm{a}}$, Chad J. Penn ${ }^{\mathrm{b}}$, Carlos A.C. Crusciol ${ }^{\mathrm{a}, *}$, Juliano C. Calonego $^{\mathrm{a}}$ \\ a São Paulo State University (UNESP), College of Agricultural Sciences, Department of Crop Science, P. O. Box 237, 18610-307, Botucatu, State of São Paulo, \\ Brazil \\ ${ }^{\mathbf{b}}$ National Soil Erosion Research, United States Department of Agriculture, West Lafayette, 47907, IN, United States
}

\section{A R T I C L E I N F O}

\section{Article history:}

Received 18 August 2016

Received in revised form 17 February 2017

Accepted 20 February 2017

Available online 7 March 2017

\section{Keywords:}

Soil acidity

Dolomitic lime

Humic substances

Root growth

\begin{abstract}
A B S T R A C T
Improving soil organic matter (SOM) quality in tropical acid soils is important for increasing the sustainability of agricultural ecosystems. This research evaluated the effect of the surface application of lime and phosphogypsum on the quality and amount of SOM in a long-term crop rotation under no-till conditions. The research was performed in a kaolinitic, thermic Typic Haplorthox for 12 years with annual crops under no-till. The treatments included no soil amendments, and amendment with phosphogypsum, lime, and lime + phosphogypsum. After three applications of soil amendments (2002, 2004, and 2010), surface liming increased the SOM input through addition of aboveground and root biomass, varying amount according to crop species, growing season, and soil depth. Although phosphogypsum had no effect on plant biomass production, the application of phosphogypsum with lime increased nitrogen $(\mathrm{N})$ by up to $50 \%$ in the uppermost soil depths. The application of lime alone significantly increased the total organic carbon (TOC) at all depths, although the greatest effects were observed at $0.10-0.20$ and $0.20-0.40 \mathrm{~m}$, with an increase of $44 \%$ and $41 \%$, respectively. Moreover, lime + phosphogypsum also exhibited the highest potential for $\mathrm{C}$ mineralization, which was attributed to an increased proportion of TOC as particulate organic carbon (POC). The proportion of TOC as humin and fulvic acid increased with the application of lime + phosphogypsum at $0-0.05 \mathrm{~m}$, with an increase from $55 \%$ to $92 \%$ and from $1.4 \%$ to $1.6 \%$, respectively. Overall, the combination of lime and phosphogypsum increased both the labile and stable $C$ pools.
\end{abstract}

(C) 2017 Elsevier B.V. All rights reserved.

\section{Introduction}

The positive results of conservation agriculture in tropical areas are related to increased soil organic matter (SOM) pools, which have been considered the main indicators of soil quality (Feller and Beare, 1997; Zech et al., 1997). In highly weathered soils, such as Oxisols and Ultisols, which are naturally infertile, SOM is the largest source of cation exchange capacity (CEC) and therefore plays a crucial role in nutrient availability and crop yield (Sposito, 2008). The CEC from SOM is due to certain SOM pools that are rich in acidic functional groups, comprising 70-90\% of CEC (Illés and Tombácz, 2006; Caires et al., 2006). In addition to CEC, these substances can improve water-holding capacity and soil structure, thereby providing a better plant growth environment (Stevenson, 1994). Due to high reactivity, humic substances have been

\footnotetext{
* Corresponding author.

E-mail address: crusciol@fca.unesp.br (C.A.C. Crusciol).
}

considered the most important SOM pool for Oxisols and Ultisols, having profound effects on soil chemical (Haynes and Naidu, 1998) and physical properties (Bronick and Lal, 2005; Briedis et al., 2012) that can potentially improve crop productivity and prevent land degradation processes. Although generally resistant to biodegradation, the amount of these recalcitrant compounds in the soil is low in regions characterized by high temperature and high humidity, which is possibly due to high SOM decomposition rates (Wang et al., 2016). In addition to increased decomposition rates of organic residues, tropical soils have been severely affected by soil acidity issues that reduce SOM input from plants (Garbuio et al., 2011).

Soil acidity affects approximately $30 \%$ of the world's arable land (Von Uexkuell and Mutert, 1995). Chemical characteristics associated with acid soils, such as deficiencies of essential nutrients (such as $\mathrm{Ca}^{2+}$ and $\mathrm{Mg}^{2+}$ ), and $\mathrm{Al}$ toxicity, are considered major factors that reduce SOM input (Soratto and Crusciol, 2008; Garbuio et al., 2011; Crusciol et al., 2016). Caires et al. (2006) found that the low availability of basic cations associated with high levels 
of free $\mathrm{Al}$ in the soil solution frequently limits plant growth (aboveground and root biomass) in highly weathered soils; consequently, this reduced the amount of organic residues added to the soil. Application of lime materials to the soil surface is the most common and efficient practice for reducing soil acidity in NT systems (Fageria and Nascente, 2014; Crusciol et al., 2016). However, due to the low solubility of lime materials in soils, some researchers have reported a reduced effect of lime in the subsoil layers (Caires et al., 2006; Meda et al., 2002). Because of the limited ability of surface liming to impact subsoil layers, low subsoil levels of $\mathrm{Ca}^{2+}$ and high levels of toxic $\mathrm{Al}^{3+}$ can still limit growth in Oxisols (Soratto and Crusciol, 2008). Due to its higher solubility and mobility compared to those of limestone, phosphogypsum has been studied by several researchers as a possible complement to liming to reduce $\mathrm{Al}$ toxicity and increase $\mathrm{Ca}$ availability in subsurface soil layers (Sumner et al., 1986; Caires et al., 2011; Crusciol et al., 2016). This subsoil chemical improvement has been shown to favor greater proliferation and development of roots. Root growth serves as a source for SOM (Oates and Calswell, 1985; Haynes and Naidu, 1998), although subsoil acidity presents severe chemical restrictions on root growth, reducing $C$ inputs into the soil via rhizo-deposition and dead root residues (Briedis et al., 2012). Kraus et al. (2004) found that soil fertility can significantly influence the addition of organic compounds that are considered to be primary precursors to recalcitrant organic molecules, which determine the CEC for Oxisols and Ultisols.

In a study on the effect of $C$ inputs via exudates and dead tissues on the composition of recalcitrant compounds in a rice root system, Farias et al. (2005) found that the addition of organic-C provided an increase of $65 \%$ in the $C$ content of the humin fraction, followed by smaller increases in the fulvic acid fraction (35\%). In addition to SOM input, Briedis et al. (2012) found that Ca addition using lime is fundamental for stabilizing SOM. The associations of SOM with mineral particles through polyvalent cations have been considered to be one of the most important mechanisms for improving the protection and storage of SOM in highly weathered soils (Feller and Beare, 1997). Therefore, management techniques to alleviate soil acidity, neutralize toxic elements, and increase polyvalent cations, such as $\mathrm{Ca}$ and $\mathrm{Mg}$, throughout the soil profile are required to maintain the SOM content in tropical soils.

Some long-term studies have confirmed the potential for surface lime applications to increase organic carbon (OC) storage in highly weathered soils by increasing plant growth and therefore SOM input (Castro et al., 2015). However, there is no scientific information supporting improvements on SOM pools with high stability, especially in tropical regions with hot and wet summers where SOM decomposition rates are high. Furthermore, Garbuio et al. (2011) emphasized the importance and necessity of experiments to understand the long-term impact of soil amendments on several SOM pools, particularly on humic substances that play a major role in soil fertility. Therefore, new strategies that increase OC storage in Oxisols, including in the subsoil, have been considered critical for increasing the capacity and sustainability of tropical agriculture NT systems, conducted with a crop rotation scheme.

The current study was based on the following hypotheses: a) the surface application of lime will increase SOM input at the surface and in the subsoil; b) soil amendments for amelioration of soil acidity improve $\mathrm{OC}$ stability and $\mathrm{N}$ availability in highly weathered soils; c) due to the high mobility of sulfate, the addition of phosphogypsum to lime applications is more efficient for increasing and stabilizing humic compounds in the subsurface soil than are individual applications of lime; and d) the application of soil amendments increases OC storage. Therefore, this study aimed to evaluate the dry matter inputs and the changes in total, particulate, and mineral-associated organic carbon, total and particulate nitrogen, and humic substances content in the profile of a Typic Haplorthox as affected by the surface application of lime and phosphogypsum under a long term cropping experiment under no-till.

\section{Material and methods}

\subsection{Site description}

The experiment was conducted in São Paulo State, Brazil ( $48^{\circ}$ $23^{\prime} \mathrm{W}, 22^{\circ} 51^{\prime} \mathrm{S}$ and $765 \mathrm{~m}$ ), for 12 years under no-till cropping management. The soil was classified as a sandy clay loam kaolinitic and thermic Typic Haplorthox (USDA, 1999). According to Köeppen's classification, the climate is Cwa, with a dry winter and hot wet summer. The annual average maximum and minimum temperature are 15.3 and $26.1^{\circ} \mathrm{C}$, respectively, with monthly rainfall averages between 38 and $224 \mathrm{~mm}$, and accumulated precipitation of $1,359 \mathrm{~mm}$, of which $75 \%$ occurs from October to March.

The soil chemical attributes were determined $(0-0.20 \mathrm{~m})$ according to the methodology proposed by van Raij et al. (2001). The soil $\mathrm{pH}$ was determined in a $0.01 \mathrm{~mol} \mathrm{~L}^{-1} \mathrm{CaCl}_{2}$ suspension (1:2.5 soil:solution). Soil organic matter was determined by chromic acid digestion based on Heanes (1984). The total acidity at $\mathrm{pH} 7.0(\mathrm{H}, \mathrm{Al})$ was extracted by calcium acetate $\left(0.5 \mathrm{~mol} \mathrm{~L}^{-1}\right.$ at $\left.\mathrm{pH} 7.0\right)$ and determined by titration with $0.025 \mathrm{~mol}$ $\mathrm{L}^{-1} \mathrm{NaOH}$ solution. Exchangeable $\mathrm{Al}$ was extracted with neutral $1 \mathrm{~mol} \mathrm{~L}^{-1} \mathrm{KCl}$ in a 1:10 soil:solution ratio and determined by titration with $0.025 \mathrm{~mol} \mathrm{~L}^{-1} \mathrm{NaOH}$ solution. The available $\mathrm{P}$ and exchangeable basic cations $\left(\mathrm{Ca}_{\mathrm{ex}}, \mathrm{Mg}_{\mathrm{ex}}\right.$, and $\mathrm{K}_{\mathrm{ex}}$ ) were extracted using an ion-exchange resin (van Raij et al., 1986). The phosphorus concentrations in the extracts were determined by a colorimetric method (Murphy and Riley, 1962) with a FEMTO 600S spectrophotometer. Concentrations of $\mathrm{Ca}^{2+}, \mathrm{Mg}^{2+}$, and $\mathrm{K}^{+}$in the extracts were determined by an atomic absorption/flame-emission spectrophotometer (Shimadzu AA-6300). The cation exchange capacity (CEC) was obtained by summing the individual cations $(\mathrm{H}, \mathrm{Al}, \mathrm{K}, \mathrm{Ca}$, and $\mathrm{Mg}$ ):

CEC $\left(\mathrm{mmol}_{\mathrm{c}} \mathrm{dm}^{-3}\right)=C a_{e x}+M g_{e x}+K_{e x}+$ total acidity

The base saturation (BS) values were calculated by dividing the sum of the equivalents of $\mathrm{K}, \mathrm{Mg}$, and Ca by the CEC and multiplying by 100 :

$B S(\%)=\left(C a_{e x}+M g_{e x}+K_{e x}\right) 100 / C E C$

Before establishing the experiment in 2002, the topsoil $(0-0.20 \mathrm{~m})$ had the following chemical and granulometric characteristics: organic matter, $20.9 \mathrm{~g} \mathrm{dm}^{-3} ; \mathrm{pH}\left(1: 2.5 \mathrm{soil} / \mathrm{CaCl}_{2}\right.$ suspension $0.01 \mathrm{~mol} \mathrm{~L}^{-1}$ ), 4.2; $\mathrm{P}$ (resin), $9.2 \mathrm{mg} \mathrm{dm}^{-3}$; exchangeable $\mathrm{Al}, \mathrm{K}, \mathrm{Ca}$, and $\mathrm{Mg} 2.3,1.2,14.0$, and $5.0 \mathrm{mmol}_{\mathrm{c}} \mathrm{dm}^{-3}$, respectively; total acidity in $\mathrm{pH} 7.0(\mathrm{H}+\mathrm{Al}) 37 \mathrm{mmol}_{\mathrm{c}} \mathrm{dm}^{-3}$, cation exchange capacity (CEC) $58 \mathrm{mmol}_{\mathrm{C}} \mathrm{dm}^{-3}$; and sand, silt, and clay contents of 545,108 , and $347 \mathrm{~g} \mathrm{~kg}^{-1}$, respectively. In general, this soil was typical of acidic Oxisols found in Brazil.

\subsection{Experimental design and treatments establishment}

A randomized complete block design was used with four replications. Each plot had an area of $46.8 \mathrm{~m}^{2}(5.2 \mathrm{~m} \times 9.0 \mathrm{~m})$. The following treatments were applied: (i) control (no dolomite lime and phosphogypsum), (ii) phosphogypsum (2.1 $\mathrm{Mgha}^{-1}$ ), (iii) dolomite lime (2.0 $\mathrm{Mgha}^{-1}$ ) and (iv) $2.0 \mathrm{Mg} \mathrm{ha}^{-1}$ dolomite lime and $2.1 \mathrm{Mgha}^{-1}$ phosphogypsum. The dolomite limestone used was an anhydrous carbonate mineral grounded, composed of $23.3 \%$ $\mathrm{CaO}$ and $17.5 \% \mathrm{MgO}$. In physical analysis of the dolomite limestone, 
Table 1

Crops grown and the treatment application scheme during the experimental period.

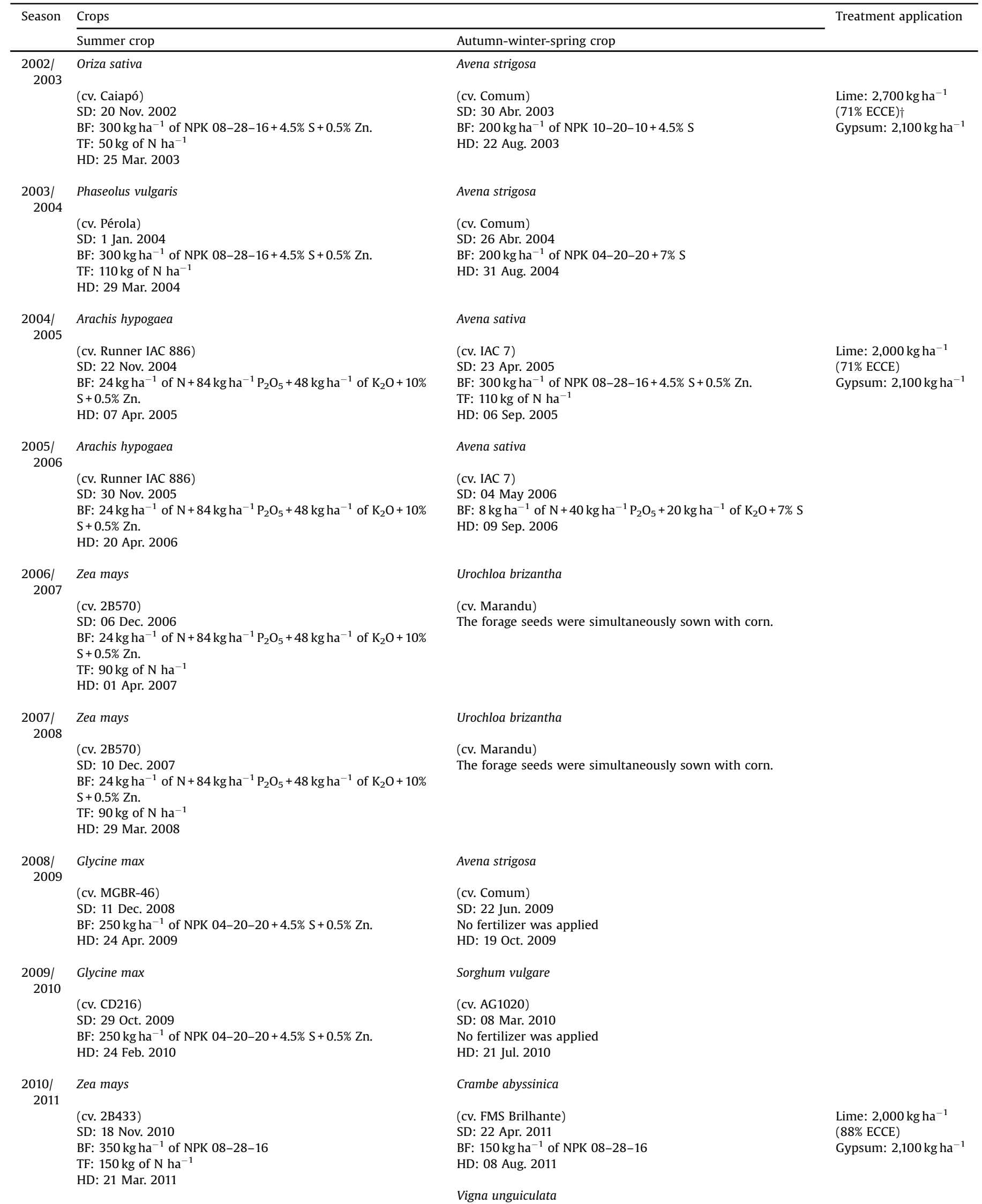


Table 1 (Continued)

\begin{tabular}{|c|c|c|c|}
\hline \multirow[t]{2}{*}{ Season } & \multicolumn{2}{|l|}{ Crops } & \multirow[t]{2}{*}{ Treatment application } \\
\hline & Summer crop & Autumn-winter-spring crop & \\
\hline & & $\begin{array}{l}\text { SD: } 19 \text { Sep. } 2011 \\
\text { BF: } 200 \mathrm{~kg} \mathrm{ha}^{-1} \text { of NPK 04-20-20 } \\
\text { HD: } 18 \text { Dec. } 2011\end{array}$ & \\
\hline $\begin{array}{r}2011 / \\
2012\end{array}$ & $\begin{array}{l}\text { Zea mays } \\
\text { (cv. } 2 \mathrm{~B} 433 \text { ) } \\
\text { SD: } 22 \mathrm{Dec} .2011 \\
\text { BF: } 350 \mathrm{~kg} \mathrm{ha}^{-1} \text { of NPK } 08-28-16 \\
\text { TF: } 150 \mathrm{~kg}^{\mathrm{N}} \mathrm{N} \mathrm{ha} \mathrm{ha}^{-1} \\
\text { HD: } 27 \mathrm{Apr} .2012\end{array}$ & $\begin{array}{l}\text { Crambe abyssinica } \\
\text { (cv. FMS Brilhante) } \\
\text { SD: } 04 \text { May } 2012 \\
\text { BF: } 150 \mathrm{~kg} \mathrm{ha}^{-1} \text { of NPK 08-28-16 } \\
\text { HD: } 23 \text { Aug. } 2012 \\
\text { Vigna unguiculata } \\
\text { SD: } 18 \text { Sep. } 2012 \\
\text { BF: } 200 \mathrm{~kg} \mathrm{ha}^{-1} \text { of NPK } 08-28-16 \\
\text { HD: } 03 \text { Jan. } 2013\end{array}$ & \\
\hline 2013 & $\begin{array}{l}\text { Pennisetum glaucum } \\
\text { (cv. ADR300) } \\
\text { SD: } 06 \text { Feb. } 2013 \\
\text { No fertilizer was applied } \\
\text { MD: } 27 \text { Mar. } 2013\end{array}$ & $\begin{array}{l}\text { Triticum aestivum } \\
\text { (cv. CD116) } \\
\text { SD: } 18 \text { Apr. } 2013 \\
\text { BF: } 35 \mathrm{~kg} \mathrm{ha}^{-1} \text { of } \mathrm{N}+70 \mathrm{~kg} \mathrm{ha}^{-1} \mathrm{P}_{2} \mathrm{O}_{5}+40 \mathrm{~kg} \mathrm{ha}^{-1} \text { of } \mathrm{K}_{2} \mathrm{O}+11 \mathrm{~kg} \text { of } \\
\text { ha } \\
\text { HD: } 22 \text { Aug. } 2013 \\
\text { HD } 22 \text { of }\end{array}$ & \\
\hline $\begin{array}{r}2013 / \\
2014\end{array}$ & $\begin{array}{l}\text { Phaseolus vulgaris } \\
\text { (cv. Pérola) } \\
\text { SD: } 27 \text { Nov. } 2013 \\
\text { BF: } 10 \mathrm{~kg} \mathrm{ha}^{-1} \text { of } \mathrm{N}+50 \mathrm{~kg} \mathrm{ha}^{-1} \mathrm{P}_{2} \mathrm{O}_{5}+50 \mathrm{~kg} \mathrm{ha}^{-1} \text { of } \mathrm{K}_{2} \mathrm{O}+11 \mathrm{~kg} \text { of } \\
\text { ha } \\
\text { TF: } 100 \mathrm{~kg} \text { of } \mathrm{N} \mathrm{ha} \mathrm{ha}^{-1} \mathrm{Zn} \text {. } \\
\text { HD: } 17 \mathrm{Feb} .2014\end{array}$ & $\begin{array}{l}\text { Triticum aestivum } \\
\text { (cv. CD116) } \\
\text { SD: } 11 \text { Mar. } 2014 \\
\text { BF: } 35 \mathrm{~kg} \mathrm{ha}^{-1} \text { of } \mathrm{N}+70 \mathrm{~kg} \mathrm{ha}^{-1} \mathrm{P}_{2} \mathrm{O}_{5}+40 \mathrm{~kg} \mathrm{ha}^{-1} \text { of } \mathrm{K}_{2} \mathrm{O}+11 \mathrm{~kg} \text { of } \\
\text { ha }^{-1} \mathrm{~S}+12 \mathrm{~kg}^{-1} \mathrm{ha}^{-1} \mathrm{Zn} . \\
\text { HD: } 23 \mathrm{Jun} .2014\end{array}$ & \\
\hline $\begin{array}{r}2014 / \\
2015\end{array}$ & $\begin{array}{l}\text { Phaseolus vulgaris } \\
\text { (cv. Pérola) } \\
\text { SD: } 01 \mathrm{Dec} .2014 \\
\text { BF: } 10 \mathrm{~kg} \mathrm{ha}^{-1} \text { of } \mathrm{N}+50 \mathrm{~kg} \mathrm{ha}^{-1} \mathrm{P}_{2} \mathrm{O}_{5}+50 \mathrm{~kg} \mathrm{ha}^{-1} \text { of } \mathrm{K}_{2} \mathrm{O}+11 \mathrm{~kg} \text { of } \\
\text { ha } \\
\text { TF: } 100 \mathrm{~kg} \text { of } \mathrm{N} \mathrm{ha} \mathrm{kg}^{-1} \mathrm{Zn} . \\
\text { HD: } 03 \text { Mar. } 2015\end{array}$ & & \\
\hline
\end{tabular}

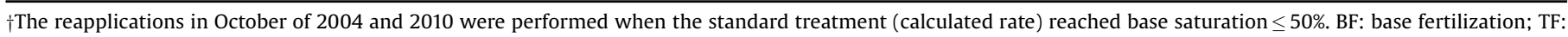
topdressing fertilization; SD: sowing date; HD: harvest date; MD: management date.

$68.8,92.4$, and $99.7 \%$ of particles passed 50,20 , and 10 mesh sieves, respectively. In the first application (at the establishment of the experiment), the rate (R) was calculated to increase the base saturation in the topsoil $(0-0.20 \mathrm{~m})$ to $70 \%$; this calculation was performed using Eq. (3), as described by Cantarella et al. (1998):

$R\left(\mathrm{Mg} \mathrm{ha}^{-1}\right)=\left(B S_{\text {target }}-B S\right) C E C /(E C C E 10)$

where ECCE is the effective calcium carbonate equivalent of the dolomite; $B S_{\text {target }}$ is the target base saturation (70\%); and $B S$ is the base saturation determined via soil chemical analysis, as calculated by Eq. (2). The phosphogypsum was composed of $20 \% \mathrm{Ca}, 16 \% \mathrm{~S}$ and residual $\mathrm{P}$ and $\mathrm{F}(0.1 \%)$, and the rate $(P R)$ was calculated using Eq. (4), according to the method proposed by van Raij et al. (1986):

$P R\left(\mathrm{~kg} \mathrm{ha}^{-1}\right)=6 C L$

where $C L$ is the clay content $\left(\mathrm{g} \mathrm{kg}^{-1}\right)$ in the 0.20 - to $0.40-\mathrm{m}$ soil layer. During the study period, the treatments were applied three times to the soil surface without mechanical incorporation, and different species were cropped in-season and off-season from 2002 to 2015. Details of the crop sequences and fertilizer management are shown in Table 1.

The soil amendment reapplications in October of 2004 and 2010 were performed when the standard treatment reached a base saturation of less than or equal to $50 \%$. When lime reapplication was necessary, the phosphogypsum rate was also reapplied.

\subsection{Crop management, plant sampling and analyses}

The Triticum aestivum (cv. CD116) was sown at a density of 80 seeds $\mathrm{m}^{-1}$, with $0.17 \mathrm{~m}$ spacing between rows. The Phaseolus vulgaris (cv. Pérola) was sown using a row spacing of $0.45 \mathrm{~m}$ with 16 seeds $\mathrm{m}^{-1}$ in each row. Both crops were cropped in the 2013/2014 and 2014/2015 growing seasons.

For each crop, the aboveground and root biomass was collected at the flowering stage. Ten random plants per plot were removed for the aboveground biomass determination. The root growth was measured via eight individual soil samples randomly taken from each plot to form a composite sample. The soil samples were taken from the $0-0.05,0.05-0.10$, and $0.10-0.20$ m layers with a $69-\mathrm{mm}$ diameter cutting tip soil probe. For the soil samples collected at $0.20-0.40 \mathrm{~m}$, a $49-\mathrm{mm}$-diameter cutting tip probe was used. The roots were carefully separated from the soil and other residues by washing under a flow of swirling water, according to the method described by Oussible et al. (1992). All of the biomass samples were dried in a forced air oven at $65^{\circ} \mathrm{C}$ for $72 \mathrm{~h}$ and weighed for dry mass determination.

\subsection{Soil sampling and chemical analyses}

Twelve years after treatment establishment, the soil samples were randomly collected at depths of $0.00-0.05,0.05-0.10,0.10$ 
0.20 and $0.20-0.40 \mathrm{~m}$ with a soil probe two months after wheat harvest (Oct. 2014). The samples were air-dried, sieved (2-mm) and analyzed according to van Raij et al. (2001) to determine the chemical properties ( $\mathrm{pH}$, exchangeable $\mathrm{Al}^{3+}, \mathrm{Ca}^{2+}$, and $\mathrm{Mg}^{2+}$, and base saturation).

The total organic carbon (TOC) and total nitrogen (TN) were measured using an elemental analyzer (LECO-TruSpec1 CHN, Leco Corp., St. Joseph, MI, USA). Soil organic matter physical fractionation was performed according to the method proposed by Cambardella and Elliot (1994). A $20 \mathrm{~g}$ soil sample (air-dried and sieved through a 2-mm mesh) was homogenized in an $80 \mathrm{~mL}$ sodium hexametaphosphate solution $\left(5 \mathrm{~g} \mathrm{~L}^{-1}\right)$. The samples were horizontally shaken for $15 \mathrm{~h}$ and sieved through $0.053-\mathrm{mm}$ mesh sieves using deionized water. The retained material was transferred to aluminum dishes and dried at $45^{\circ} \mathrm{C}$ in a forced-air oven to a constant mass, after which it was ground with a porcelain mortar and pestle and homogenized. The particulate nitrogen (PN) and particulate organic carbon (POC) were measured via dry combustion with an elemental analyzer, which is defined as the $\mathrm{N}$ and $\mathrm{C}$ content in the $0.053-2 \mathrm{~mm}$ soil fraction. The mineral-associated organic carbon (MOC) was calculated by the difference between TOC and POC.

The chemical fractionation of soil organic matter was determined according to the method described by Ciavatta et al. (1990), which uses Superlite DAX-8 resin to separate non-humified substances from humic fractions. A total of $10 \mathrm{~g}$ of soil samples (air-dried, sieved through 2-mm mesh, and without litter fraction) were weighed in $250-\mathrm{mL}$ centrifuge tubes, in which $100 \mathrm{~mL}$ of $0.1 \mathrm{M} \mathrm{NaOH}$ plus $0.1 \mathrm{M} \mathrm{Na}_{4} \mathrm{P}_{2} \mathrm{O}_{7}$ were added. Dinitrogen gas was bubbled through the solution for $2 \mathrm{~min}$; the samples were shaken for $2 \mathrm{~h}$ at 160 oscillations per minute followed by centrifugation at 14,000 RPM for $25 \mathrm{~min}$. The suspension was filtered through a $0.45-\mu \mathrm{m}$ Millipore filter. The remaining solids (humin and mineral matter) were stored for subsequent analysis. Moreover, $25 \mathrm{~mL}$ of the extract were transferred into a centrifuge tube and acidified to a $\mathrm{pH}$ of less than 2 by slowly adding $9-10 \mathrm{~mL}$ of $0.5 \mathrm{M} \mathrm{H}_{2} \mathrm{SO}_{4}$, followed by centrifuging at 9,000 RPM for $25 \mathrm{~min}$. The precipitate (humic acid fraction, HA) was separated and redissolved with $20 \mathrm{~mL}$ of $0.3 \mathrm{M}$ $\mathrm{NaOH}$ and stored for $\mathrm{C}$ determination. The supernatant solution was slowly applied to a column (a common 60-mL plastic syringe) containing approximately $6 \mathrm{~cm}^{3}$ of Superlite DAX-8 resin previously equilibrated in $0.005 \mathrm{M} \mathrm{H}_{2} \mathrm{SO}_{4}$. The eluate (non-humic substances) was discarded and the column was eluted with $20 \mathrm{~mL}$ of $0.005 \mathrm{M} \mathrm{H}_{2} \mathrm{SO}_{4}$. The retained fraction (fulvic acid fraction, $\mathrm{FA}$ ), generally brown in color, was eluted using $20 \mathrm{~mL}$ of $0.5 \mathrm{M} \mathrm{NaOH}$, discarding the first $3 \mathrm{~mL}$, and was collected in a $125-\mathrm{mL}$ glass bottle for $\mathrm{C}$ determination.

The organic C in humin (C-HU), humic (C-HA) and fulvic (C-FA) acid solutions were determined using a wet oxidation method adapted from Heanes (1984). A total of $1 \mathrm{~g}$ (for solid) or $15-\mathrm{mL}$ (for liquid) of each sample was placed in a 125 - $\mathrm{mL}$ Erlenmeyer flask, in which $10 \mathrm{~mL}$ of $\mathrm{K}_{2} \mathrm{Cr}_{2} \mathrm{O}_{7}$ solution $\left(49.02 \mathrm{~g} \mathrm{~L}^{-1}\right)$ and $20 \mathrm{~mL}$ of $98 \%$ $\mathrm{H}_{2} \mathrm{SO}_{4}$ were carefully added while manually agitated. After three hours, the solution was brought to approximately $50 \mathrm{~mL}$ with DI water. The solution was transferred to a volumetric flask and the final volume was adjusted to $100 \mathrm{~mL}$ with DI water. The organic carbon was measured using a Milton Roy Spectronic 21D spectrophotometer at $600 \mathrm{~nm}$. A standard curve was prepared using a sucrose solution $\left(4.754 \mathrm{~g} \mathrm{~L}^{-1}\right)$ containing $2 \mathrm{mg}$ organic $\mathrm{C} \mathrm{mL}^{-1}$.

The carbon mineralization (\% of TOC) was analyzed according to the methodology described by Bernal et al. (1998). Moreover, $100 \mathrm{~g}$ of soil sample (air-dried and sieved through a 2-mm sieve) were placed in incubation flasks (0.925-L Mason jars $\left.{ }^{\circledR}\right)$. Distilled water was added to adjust the soil moisture to $70 \%$ of field capacity. To determine the amount of $\mathrm{CO}_{2}$ released (i.e., OC mineralized), a $50-\mathrm{mL}$ beaker with $20 \mathrm{~mL}$ of $0.3 \mathrm{M} \mathrm{NaOH}$ was placed on top of the soil in each incubation flask. Each incubation flask was kept sealed between sampling events. Periodically, the trapped $\mathrm{CO}_{2}$ was quantified by $\mathrm{NaOH}$ titration (using $0.5 \mathrm{M} \mathrm{HCl}$ as titrant) after $10 \mathrm{~mL}$ of $0.05 \mathrm{M} \mathrm{BaCl}_{2}$ was added to the solution.

\subsection{Statistical analyses}

To further estimate the OC in humic substances (C-HA, C-FA and $\mathrm{C}-\mathrm{HU}$ ) and TOC, a conversion factor of 1.14 was used to convert the wet $C$ analysis method to values from dry combustion, as proposed by Rheinheimer et al. (2008). All of the data were analyzed using two-way ANOVA. The treatments were considered fixed effects. Significant differences between the means were determined using Fisher's protected LSD test. The effects were considered significant at $\mathrm{P} \leq 0.05$ for the aboveground biomass and SOM parameters, and $\mathrm{P} \leq 0.10$ for the root dry matter data. A higher probability of the root system evaluation was used because these characteristics are naturally more variable (Fageria and Moreira, 2011). Pearson's correlation analysis was conducted to investigate the relationship between soil chemical properties ( $\mathrm{pH}, \mathrm{Al}, \mathrm{Ca}, \mathrm{Mg}$ and base saturation) and $\mathrm{OC}$ pools in the soil profile.

Table 2

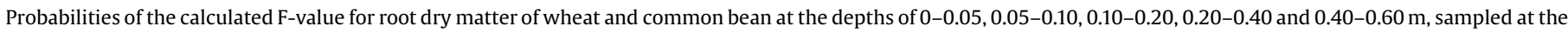
flowering stage for two growing seasons (2013/2014 and 2014/2015).

\begin{tabular}{|c|c|c|c|c|c|c|c|c|}
\hline \multirow{3}{*}{$\begin{array}{l}\text { Layer } \\
(\mathrm{m})\end{array}$} & \multicolumn{4}{|l|}{ F probability } & \multirow{2}{*}{\multicolumn{2}{|c|}{$\mathrm{CV}(\%)^{\dagger}$}} & \multirow{2}{*}{\multicolumn{2}{|c|}{$\mathrm{LSD}^{\ddagger}$}} \\
\hline & \multicolumn{2}{|l|}{ Blocks } & \multicolumn{2}{|l|}{ Treatments } & & & & \\
\hline & $2013 / 2014$ & $2014 / 2015$ & $2013 / 2014$ & $2014 / 2015$ & $2013 / 2014$ & $2014 / 2015$ & $2013 / 2014$ & $2014 / 2015$ \\
\hline \multicolumn{9}{|l|}{ Wheat } \\
\hline $0-0.05$ & 0.2146 & 0.5719 & 0.0246 & $<0.0001$ & 23.2 & 21.6 & 155.3 & 80.8 \\
\hline $0.05-0.10$ & 0.2174 & 0.4647 & 0.0001 & 0.0016 & 17.9 & 27.8 & 57.1 & 111.0 \\
\hline $0.10-0.20$ & 0.6065 & 0.8864 & $<0.0001$ & $<0.0001$ & 22.7 & 25.8 & 12.2 & 14.9 \\
\hline $0.20-0.40$ & 0.3203 & 0.3113 & 0.0014 & $<0.0001$ & 33.1 & 29.5 & 10.8 & 19.1 \\
\hline \multicolumn{9}{|c|}{ Common bean } \\
\hline $0-0.05$ & 0.1626 & 0.5414 & $<0.0001$ & $<0.0001$ & 22.6 & 26.4 & 28.3 & 36.2 \\
\hline $0.05-0.10$ & 0.5689 & 0.2950 & $<0.0001$ & $<0.0001$ & 18.2 & 25.3 & 22.3 & 32.2 \\
\hline $0.10-0.20$ & 0.2513 & 0.3365 & $<0.0001$ & 0.1218 & 15.4 & 20.3 & 14.4 & 26.3 \\
\hline $0.20-0.40$ & 0.3001 & 0.4903 & $<0.0001$ & $<0.0001$ & 23.4 & 18.1 & 9.3 & 5.5 \\
\hline
\end{tabular}

$\dagger$ Coefficient of variation.

$\Varangle$ Least significant difference. 
Table 3

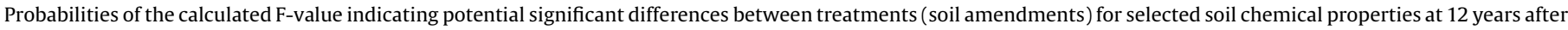
initial establishment of treatments.

\begin{tabular}{|c|c|c|c|c|}
\hline \multirow{2}{*}{$\begin{array}{l}\text { Layer } \\
\text { (m) }\end{array}$} & \multicolumn{2}{|c|}{ F probability } & \multirow[t]{2}{*}{$\mathrm{CV}(\%) \dagger$} & \multirow[t]{2}{*}{$\mathrm{LSD}_{\ddagger}^{\ddagger}$} \\
\hline & Blocks & Treatments & & \\
\hline \multicolumn{5}{|c|}{ N-Particulate } \\
\hline $0-0.05$ & 0.5026 & $<0.0001$ & 3.1 & 0.017 \\
\hline $0.05-0.10$ & 0.3482 & $<0.0001$ & 5.1 & 0.016 \\
\hline $0.10-0.20$ & 0.2851 & $<0.0001$ & 10.3 & 0.020 \\
\hline $0.20-0.40$ & 0.3112 & $<0.0001$ & 8.8 & 0.025 \\
\hline \multicolumn{5}{|l|}{ N-Total } \\
\hline $0-0.05$ & 0.2629 & $<0.0001$ & 2.9 & 0.033 \\
\hline $0.05-0.10$ & 0.7135 & 0.0002 & 6.1 & 0.047 \\
\hline $0.10-0.20$ & 0.8616 & $<0.0001$ & 7.1 & 0.047 \\
\hline $0.20-0.40$ & 0.5800 & 0.0020 & 8.4 & 0.055 \\
\hline \multicolumn{5}{|c|}{ C-Particulate } \\
\hline $0-0.05$ & 0.2658 & 0.0027 & 9.4 & 1.372 \\
\hline $0.05-0.10$ & 0.5948 & $<0.0001$ & 10.6 & 0.630 \\
\hline $0.10-0.20$ & 0.4738 & $<0.0001$ & 8.3 & 0.159 \\
\hline $0.20-0.40$ & 0.6350 & $<0.0001$ & 9.1 & 0.151 \\
\hline \multicolumn{5}{|l|}{ C-Total } \\
\hline $0-0.05$ & 0.3363 & 0.0016 & 6.8 & 1.863 \\
\hline $0.05-0.10$ & 0.2189 & $<0.0001$ & 5.2 & 0.888 \\
\hline $0.10-0.20$ & 0.2047 & 0.0006 & 9.0 & 1.265 \\
\hline $0.20-0.40$ & 0.2321 & 0.0039 & 11.4 & 1.516 \\
\hline \multicolumn{5}{|c|}{ C-Mineral-associated } \\
\hline $0-0.05$ & 0.5742 & 0.0027 & 5.4 & 1.027 \\
\hline $0.05-0.10$ & 0.3472 & 0.0168 & 9.0 & 1.168 \\
\hline $0.10-0.20$ & 0.2873 & 0.0066 & 10.3 & 1.255 \\
\hline $0.20-0.40$ & 0.3499 & 0.0034 & 9.0 & 1.051 \\
\hline \multicolumn{5}{|c|}{ POC/TOC ratio } \\
\hline $0-0.05$ & 0.4234 & 0.0026 & 4.5 & 3.162 \\
\hline $0.05-0.10$ & 0.7725 & $<0.0001$ & 7.1 & 2.631 \\
\hline $0.10-0.20$ & 0.1379 & $<0.0001$ & 5.2 & 1.125 \\
\hline $0.20-0.40$ & 0.5972 & $<0.0001$ & 8.1 & 1.573 \\
\hline \multicolumn{5}{|l|}{ C-Humin } \\
\hline $0-0.05$ & 0.9802 & 0.0004 & 12.2 & 2.781 \\
\hline $0.05-0.10$ & 0.6749 & 0.9212 & 11.6 & 1.192 \\
\hline $0.10-0.20$ & 0.2402 & 0.0201 & 14.1 & 0.689 \\
\hline $0.20-0.40$ & 0.5875 & 0.0125 & 13.9 & 0.870 \\
\hline \multicolumn{5}{|c|}{ C-Humic acids } \\
\hline $0-0.05$ & 0.3722 & 0.0011 & 5.8 & 0.111 \\
\hline $0.05-0.10$ & 0.3028 & 0.0011 & 10.5 & 0.102 \\
\hline $0.10-0.20$ & 0.1317 & $<0.0001$ & 11.1 & 0.080 \\
\hline $0.20-0.40$ & 0.3044 & 0.0004 & 12.5 & 0.092 \\
\hline \multicolumn{5}{|c|}{ C-Fulvic acids } \\
\hline $0-0.05$ & 0.8780 & 0.0001 & 7.5 & 0.028 \\
\hline $0.05-0.10$ & 0.8976 & 0.0064 & 15.2 & 0.031 \\
\hline $0.10-0.20$ & 0.4168 & $<0.0001$ & 5.9 & 0.022 \\
\hline $0.20-0.40$ & 0.9301 & 0.0013 & 13.1 & 0.032 \\
\hline \multicolumn{5}{|c|}{ C-HU/TOC ratio } \\
\hline $0-0.05$ & 0.4078 & $<0.0001$ & 8.0 & 9.961 \\
\hline $0.05-0.10$ & 0.2868 & 0.0430 & 12.7 & 12.453 \\
\hline $0.10-0.20$ & 0.2398 & 0.5292 & 15.6 & 17.148 \\
\hline $0.20-0.40$ & 0.5806 & 0.8643 & 17.6 & 13.411 \\
\hline \multicolumn{5}{|c|}{ C-HA/TOC ratio } \\
\hline $0-0.05$ & 0.3442 & 0.4945 & 8.4 & 0.989 \\
\hline $0.05-0.10$ & 0.4622 & 0.2360 & 10.8 & 1.523 \\
\hline $0.10-0.20$ & 0.2724 & 0.0019 & 9.5 & 0.773 \\
\hline $0.20-0.40$ & 0.5636 & 0.0014 & 11.4 & 0.710 \\
\hline \multicolumn{5}{|c|}{ C-FA/TOC ratio } \\
\hline $0-0.05$ & 0.3077 & 0.0360 & 7.7 & 0.149 \\
\hline $0.05-0.10$ & 0.9613 & 0.0037 & 9.5 & 0.503 \\
\hline $0.10-0.20$ & 0.5065 & 0.0043 & 6.6 & 0.581 \\
\hline $0.20-0.40$ & 0.6157 & 0.0005 & 12.7 & 0.304 \\
\hline
\end{tabular}

$\dagger$ Coefficient of variation.

$\ddagger$ Least significant difference. 


\section{Results}

\subsection{Biomass production}

In both crop species, biomass production was affected by the different treatments (Tables 2 and 3). In both growing seasons, wheat and common bean biomass (above and belowground) were positively influenced by the surface application of lime, with no significant effects from phosphogypsum alone. On average, the surface application of lime increased the aboveground biomass of wheat and common bean by up to 125 and $92 \%$, respectively, compared with the control treatment. Similar to aboveground biomass, lime application alone was sufficient to increase the wheat root dry matter by $122,210,896$, and $637 \%$ at depths of 0 to $0.05,0.05$ to $0.10,0.10$ to 0.20 , and 0.20 to $0.40 \mathrm{~m}$, respectively, based on averages between the two growing seasons. For common bean root dry matter, the values also varied according to soil depth, with increases of $81,103,43$, and $340 \%$ (Fig. 1).

The combination of lime + phosphogypsum did not significantly increase the root dry matter compared to that in the soil treated with lime alone except for the first common bean season at soil depths of 0.05 to $0.10 \mathrm{~m}$ (Fig. 1C), where the treatment increased the root dry matter by $43 \%$ compared to that in the lime-alone treatment. The application of phosphogypsum alone did not significantly increase the root dry matter compared to that in the control except for the first common bean season at soil depths of 0.20 to $0.40 \mathrm{~m}$.

\subsection{Soil results}

There were significant effects on nitrogen and OC pools in all of the evaluated soil layers due to the treatments (Table 3 ).

\subsubsection{Soil nitrogen}

The application of lime increased PN by $0.04 \mathrm{~g} \mathrm{~kg}^{-1}(13 \%)$ in the 0 - to 0.05 -m layer (Fig. 2A), whereas this effect was not observed at the next lower layer ( 0.05 to $0.10-\mathrm{m})$, where the phosphogypsum combined with lime provided the highest PN values $\left(0.19 \mathrm{~g} \mathrm{~kg}^{-1}\right)$. Despite increases in PN at the soil surface (0-0.05 and $0.05-0.10 \mathrm{~m})$, the soil amendments reduced PN below $0.10 \mathrm{~m}$ depth. However, the application of lime+phosphogypsum increased TN by $57 \%, 33 \%, 43 \%$, and $42 \%$ at depths of 0 to $0.05,0.05$ to $0.10,0.10$ to 0.20 , and 0.20 to $0.40 \mathrm{~m}$, respectively (Fig. 2B). In general, TN was positively correlated with exchangeable basic cations $\left(\mathrm{Ca}^{2+}\right.$ and $\left.\mathrm{Mg}^{2+}\right)$ and negatively correlated with exchangeable $\mathrm{Al}$ in the soil profile (Table 4 ).

\subsubsection{Forms and lability of soil carbon}

Surface liming, alone or in combination with phosphogypsum, generally resulted in increased organic carbon (OC) pools in these tropical soils, as illustrated by higher POC, TOC, and MOC contents, although the effect varied with soil depth (Figs. 2C-E). In the limeamended soil, the TOC content was $18.8,12.0,10.5$, and $9.6 \mathrm{~g} \mathrm{~kg}^{-1}$ at depths of 0 to $0.05,0.05$ to $0.10,0.10$ to 0.20 , and 0.20 to $0.40 \mathrm{~m}$, respectively. Although the addition of phosphogypsum with lime

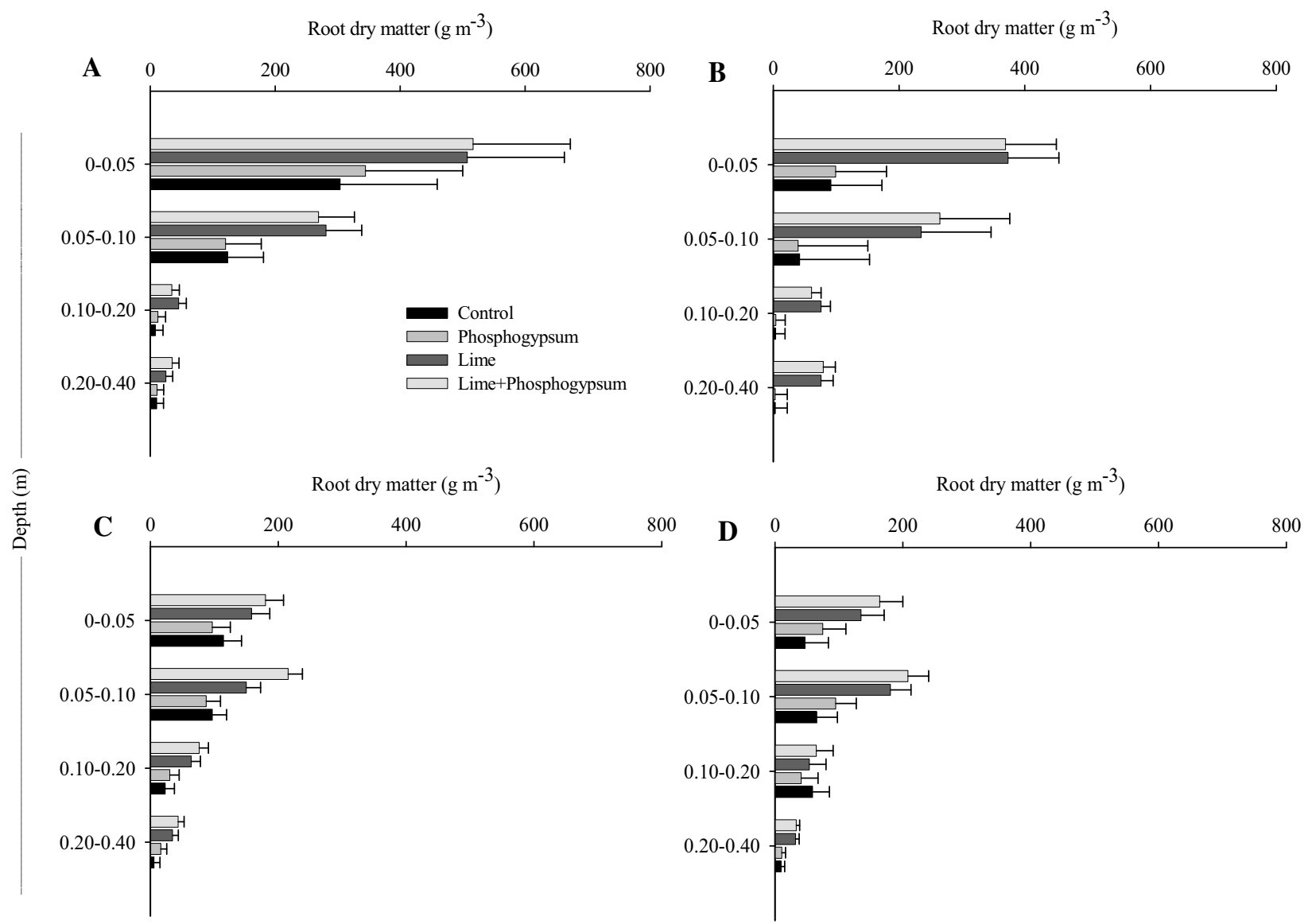

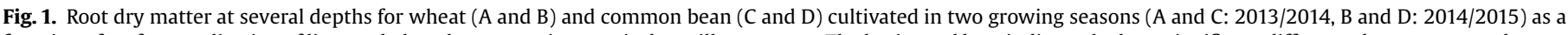

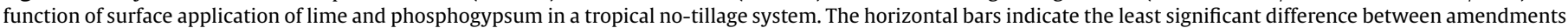
within each soil depth at $\mathrm{p} \leq 0.10$. Lime and phosphogypsum applied in 2002, 2004, and 2010 . 


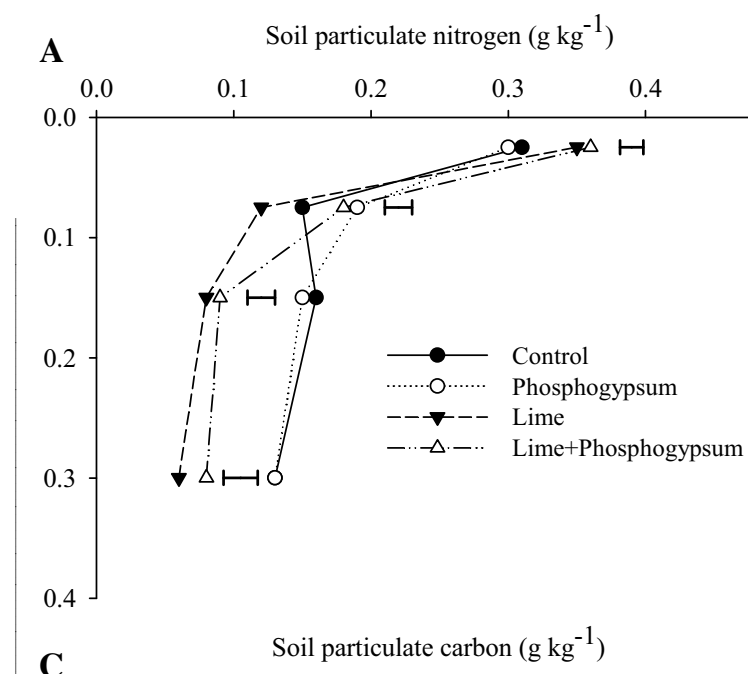

B

Soil total nitrogen $\left(\mathrm{g} \mathrm{kg}^{-1}\right)$
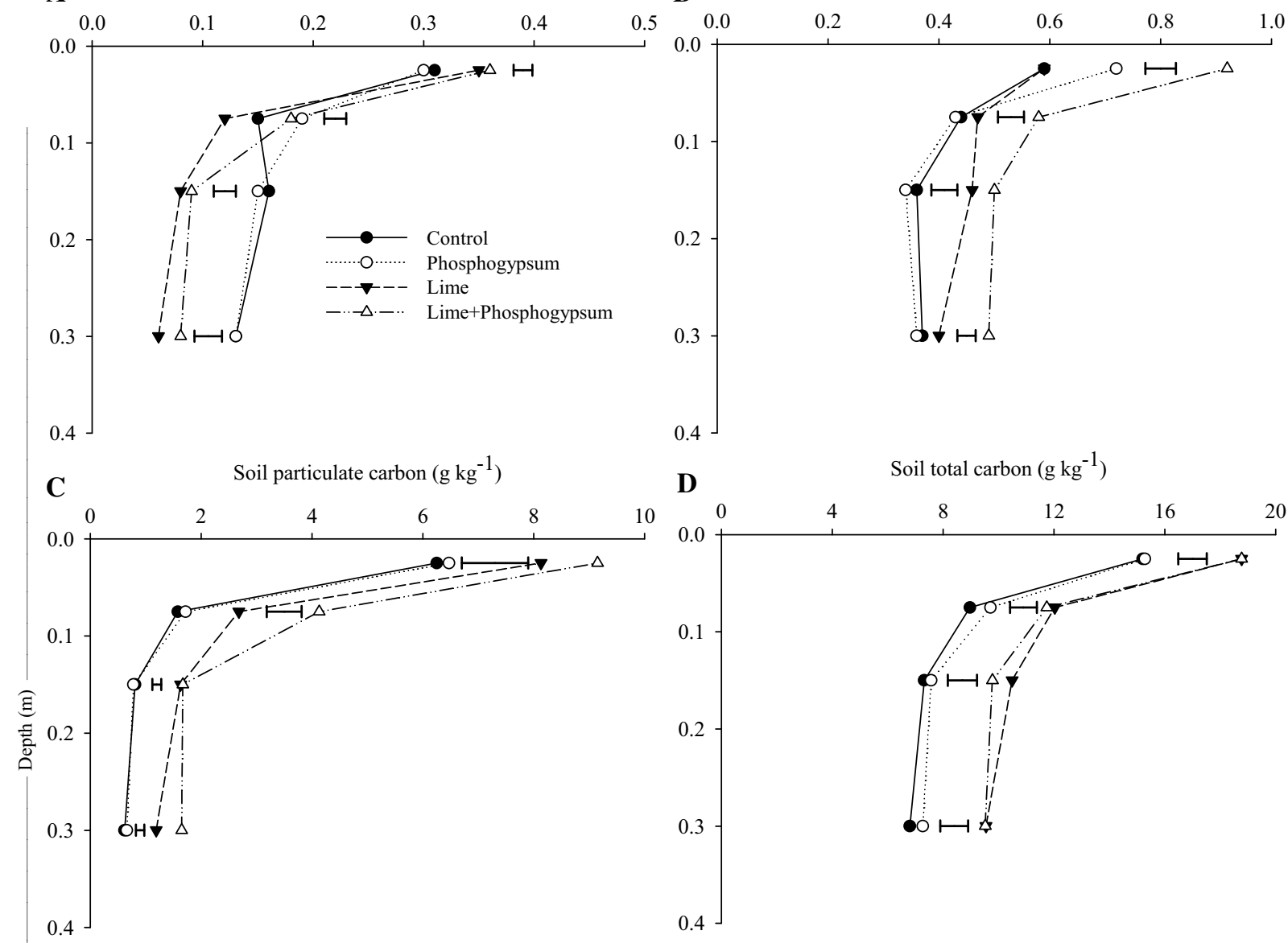

D Soil total carbon $\left(\mathrm{g} \mathrm{kg}^{-1}\right)$
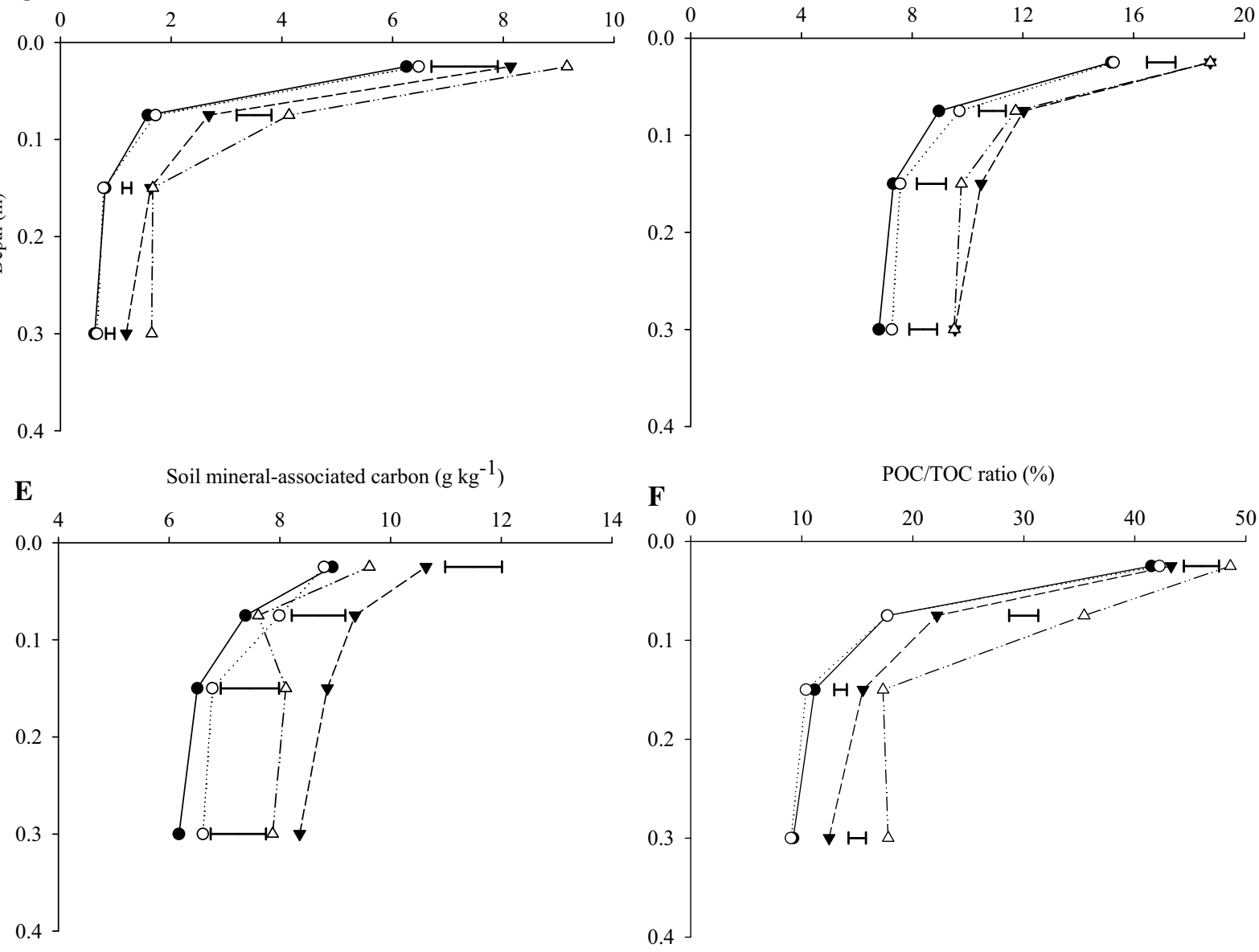

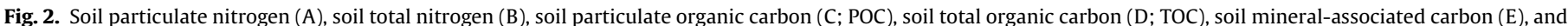

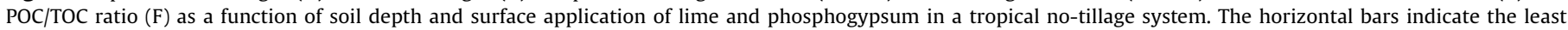
significant difference between treatments within each soil depth at $\mathrm{p} \leq 0.05$. Lime and phosphogypsum applied in 2002,2004 , and 2010 .

did not change the TOC content, the combination of both soil amendments increased POC by $52 \%$ and $42 \%$ in the 0.05 - to 0.10 and 0.20 - to 0.40 -m layers, respectively. Furthermore, the greatest $\mathrm{POC} / \mathrm{TOC}$ ratio was observed in all soil layers when phosphogypsum was applied with lime, suggesting the formation of SOM with greater lability. This effect may be related to levels of $\mathrm{Ca}$ in the soil treated with both materials because there was a positive relationship between $\mathrm{POC}$ content and soil $\mathrm{Ca}\left(\mathrm{r}^{2}=0.94\right.$; $\mathrm{p}<0.001)$. Significant relationships were observed between OC pools (except for $\mathrm{MOC}$ ) and some soil chemical attributes (exchangeable $\mathrm{Al}^{3+}, \mathrm{SO}_{4}{ }^{2-}, \mathrm{Ca}^{2+}$, and $\mathrm{Mg}^{2+}$ and base saturation; Table 4).

Surface lime application had positive effects on C-HA, C-FA, and $\mathrm{C}$-HU contents (Fig. 3A-C). The lime-amended treatments increased the C-HA content by $25 \%, 33 \%, 71 \%$, and $95 \%$ at soil depths of 0 to $0.05,0.05$ to $0.10,0.10$ to 0.20 , and 0.20 to $0.40 \mathrm{~m}$, respectively. In general, increases in the C-FA content varied approximately $18 \%$ to $137 \%$, with a greater impact from lime 
application at greater depths $(0.20$ to $0.40 \mathrm{~m})$. In the surface depth of 0.05 to $0.10 \mathrm{~m}$, lime alone was sufficient to increase the C-HU content; however, there was a synergetic effect of phosphogypsum in lime-amended plots in the 0 - to 0.05 -m layer, resulting in the highest C-HU concentration $\left(17.2 \mathrm{~g} \mathrm{~kg}^{-1}\right)$. A Pearson's correlation analysis between the soil chemical properties and the amounts of $\mathrm{OC}$ in the form of humic substances suggested that humification was favored by increased $\mathrm{pH}$, exchangeable $\mathrm{Ca}^{2+}$ and $\mathrm{Mg}^{2+}$, and base saturation and by reduced toxicity from exchangeable $\mathrm{Al}^{3+}$. Despite the relatively low impacts of the combination of lime + phosphogypsum on the C-HA, C-FA, and CHU concentrations, the highest C-HA/TOC and C-FA/TOC ratios were observed when lime was combined with phosphogypsum, suggesting that the formation of less labile OC in the subsurface layers (0.10- to $0.30-\mathrm{m}$ depths), and positive impacts on SOM quality at $0-0.05 \mathrm{~m}$ through higher proportions of $\mathrm{OC}$ as humic substances (FA and humin) (Fig. 3D-F) in the lime + phosphogypsum combination.

The higher lability of SOM represented by a greater POC/TOC ratio in the lime + phosphogypsum treatment may be related to high OC mineralization (\%TOC) rates after 73 days of incubation for all of the evaluated soil depths ( $16.1 \%$ at 0 to $0.05 \mathrm{~m} ; 14.7 \%$ at 0.05 to $0.10 \mathrm{~m}$; and $11.6 \%$ at 0.10 to $0.20 \mathrm{~m}$; Fig. $4 \mathrm{~A}, \mathrm{~B}$, and $\mathrm{C}$, respectively). Initially, in the $0-0.05$ and $0.05-0.10-\mathrm{m}$ layers, all of the treatments released similar amounts of $\mathrm{C}$ (averages of $2.0 \%$ and $2.5 \%$ of TOC, respectively). In the $0.10-0.20-\mathrm{m}$ layer, the combination of lime and phosphogypsum showed higher mineralization $(2.5 \%$ of TOC) compared to that observed in the control treatment $(1.4 \%$ of TOC). In the soil surface, the total amount of $\mathrm{C}$ released was similar among the treatments after 9 days of incubation ( $4.4 \%$ of TOC). After this period, the surface application of lime + phosphogypsum showed higher cumulative mineralized $C$ than was observed for other treatments in all soil layers. The mineralization rates varied as a function of soil depth, treatment, and incubation period.

Table 4

Probability values (P) and Pearson correlation coefficients ( $\mathrm{r}$ ) between soil organic matter pools and soil chemical properties in soils treated with lime and gypsum applications in an Oxisol under long-term no-tillage experiment ${ }^{\dagger}$.

\begin{tabular}{|c|c|c|c|c|}
\hline \multirow[b]{2}{*}{ Parameter } & \multicolumn{2}{|l|}{ TOC } & \multicolumn{2}{|l|}{ POC } \\
\hline & $r$ & $\mathrm{P}$ & $r$ & $\mathrm{P}$ \\
\hline $\mathrm{pH}$ & 0.7852 & $<0.0001$ & 0.9241 & $<0.0001$ \\
\hline $\mathrm{Al}^{3+}$ & -0.8433 & $<0.0001$ & -0.9205 & $<0.0001$ \\
\hline $\mathrm{Ca}^{2+}$ & 0.8039 & $<0.0001$ & 0.9448 & $<0.0001$ \\
\hline $\mathrm{Mg}^{2+}$ & 0.8376 & $<0.0001$ & 0.9468 & $<0.0001$ \\
\hline \multirow[t]{3}{*}{ Base saturation } & 0.7870 & $<0.0001$ & 0.9258 & $<0.0001$ \\
\hline & MOC & & $\mathrm{C}-\mathrm{HA}$ & \\
\hline & $\mathrm{r}$ & $\mathrm{P}$ & $r$ & $\mathrm{P}$ \\
\hline $\mathrm{pH}$ & 0.4565 & 0.0752 & 0.8722 & $<0.0001$ \\
\hline $\mathrm{Al}^{3+}$ & -0.5680 & 0.0224 & -0.9180 & $<0.0001$ \\
\hline $\mathrm{Ca}^{2+}$ & 0.4599 & 0.0739 & 0.8645 & $<0.0001$ \\
\hline $\mathrm{Mg}^{2+}$ & 0.5186 & 0.0403 & 0.9013 & $<0.0001$ \\
\hline \multirow[t]{3}{*}{ Base saturation } & 0.4503 & 0.0807 & 0.8528 & $<0.0001$ \\
\hline & C-FA & & C-HU & \\
\hline & r & $\mathrm{P}$ & r & $\mathrm{P}$ \\
\hline $\mathrm{pH}$ & 0.9012 & $<0.0001$ & 0.8520 & $<0.0001$ \\
\hline $\mathrm{Al}^{3+}$ & -0.9133 & $<0.0001$ & -0.8934 & $<0.0001$ \\
\hline $\mathrm{Ca}^{2+}$ & 0.9177 & $<0.0001$ & 0.8583 & $<0.0001$ \\
\hline $\mathrm{Mg}^{2+}$ & 0.9418 & $<0.0001$ & 0.8283 & $<0.0001$ \\
\hline Base saturation & 0.9187 & $<0.0001$ & 0.8636 & $<0.0001$ \\
\hline
\end{tabular}

$\dagger \mathrm{TOC}=$ Total organic carbon; $\mathrm{POC}=$ Particulate organic carbon; $\mathrm{MOC}=$ mineralassociated organic carbon; $\mathrm{C}-\mathrm{HA}=$ Organic $\mathrm{C}$ in humic acid; $\mathrm{C}-\mathrm{FA}=$ Organic $\mathrm{C}$ in fulvic acid; $\mathrm{C}-\mathrm{HU}=$ Organic $\mathrm{C}$ in humin.

\section{Discussion}

\subsection{Biomass production and organic matter input into soil}

As expected, changes in soil fertility through the surface application of lime and lime+phosphogypsum increased the biomass production of wheat and common bean (via aboveground residues and roots fragments), although the effect of phosphogypsum alone was not observed for both crops and growing seasons due to the low magnitude of residual effects and the influence of a high rainfall regime. A possible explanation for this result may the phosphogypsum chemical characteristics, which were exhausted in the soil root zone of the wheat that was cropped 30 months after the last reapplication. In a Podzolic soil, no residual effect of gypsum was reported by Weir et al. (1963) 16 months after application. According to Caires et al. (2011), in a clayey, kaolinitic, Rhodic Hapludox subtropical soil previously used for pasture, more than $50 \%$ of the applied exchangeable Ca from gypsum was leached into soil layers deeper than $0.60 \mathrm{~m}$ after 27 months. In addition to the low residual effect of phosphogypsum, several researchers have reported that aboveground residues were not influenced by the application of phosphogypsum alone (Soratto and Crusciol, 2008; Crusciol et al., 2016). Because phosphogypsum is not considered to be an acid-neutralizing material (Sumner et al., 1986), the acidity conditions in this treatment were perhaps one of the reasons for the absence of a phosphogypsum effect on crop residue returns compared to those in lime-amended plots.

In contrast, the input of organic residues into the soil (via aboveground residues and root fragments) in lime-amended soil is evident. This result can be explained by the long-term effects of surface liming on soil alkalization, $\mathrm{Ca}$ and $\mathrm{Mg}$ supply, and the neutralization of $\mathrm{Al}^{3+}$ activity (Garbuio et al., 2011; Castro et al., 2015). A Pearson's correlation analysis between the soil chemical properties $\left(\mathrm{pH}\right.$, exchangeable $\mathrm{Al}^{3+}, \mathrm{Ca}^{2+}$, and $\mathrm{Mg}^{2+}$, and base saturation) and the SOM pools supported this hypothesis (Table 4). Because crop residues are the main source of SOM (Briedis et al., 2012), the quantity and quality of the crop biomass accumulated between 2002 and 2014 impacted several of the OC pools in the soil.

\subsection{Changes in soil carbon and nitrogen pools}

As observed for wheat and common bean dry matter (Table 2), there was no significant effect from phosphogypsum alone on the soil TOC after 12 years from treatment establishment (Fig. 2D); this may be related to the low crop residue returns. However, the largest quantity of POC resulted from a combination of phosphogypsum applied with lime incorporated into all soil layers (Fig. 2C), which increased the $\mathrm{POC} / \mathrm{TOC}$ ratio (Fig. 2F) through greater surface residue contributions. The subsoil acidity presented severe chemical restrictions on root growth and the lime + phosphogypsum treatment, which probably increased the $C$ inputs into the soil via rhizodeposition and dead root residues (Briedis et al., 2012). Compared to the other treatments, the application of both soil amendments combined provided better neutralization of $\mathrm{Al}^{3+}$ toxicity and higher levels of $\mathrm{Ca}^{2+}, \mathrm{NO}_{3}{ }^{-}$, and $\mathrm{SO}_{4}{ }^{2-}$ in the soil (Crusciol et al., 2016), which may result in faster soil carbon turnover.

The higher proportion of easily degradable SOM compounds in the lime + phosphogypsum treatment (highest POC/TOC ratio; Fig. 2F) stimulated soil microbial activity and increased $C$ mineralization after $73 \mathrm{~d}$ of incubation in the topsoil layers ( 0 to $0.20 \mathrm{~m}$; Fig. 4A-C). Alvarez and Alvarez (2000) found a high positive relationship between $C$ mineralization and the light $C$ fraction $\left(r^{2}=0.83 ; p<0.001\right)$. Furthermore, Carter (1986) found 


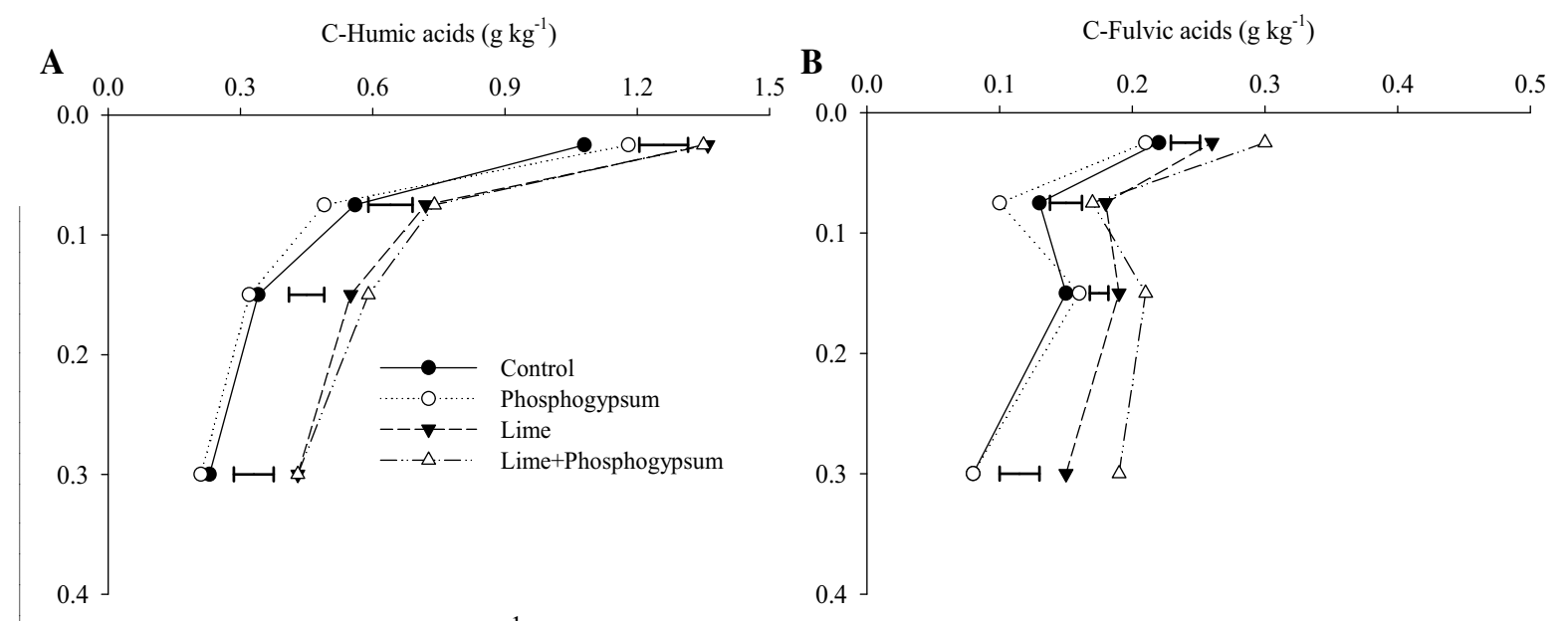

C $\quad$-Humin $\left(\mathrm{g} \mathrm{kg}^{-1}\right)$

C-HA/TOC (\%)
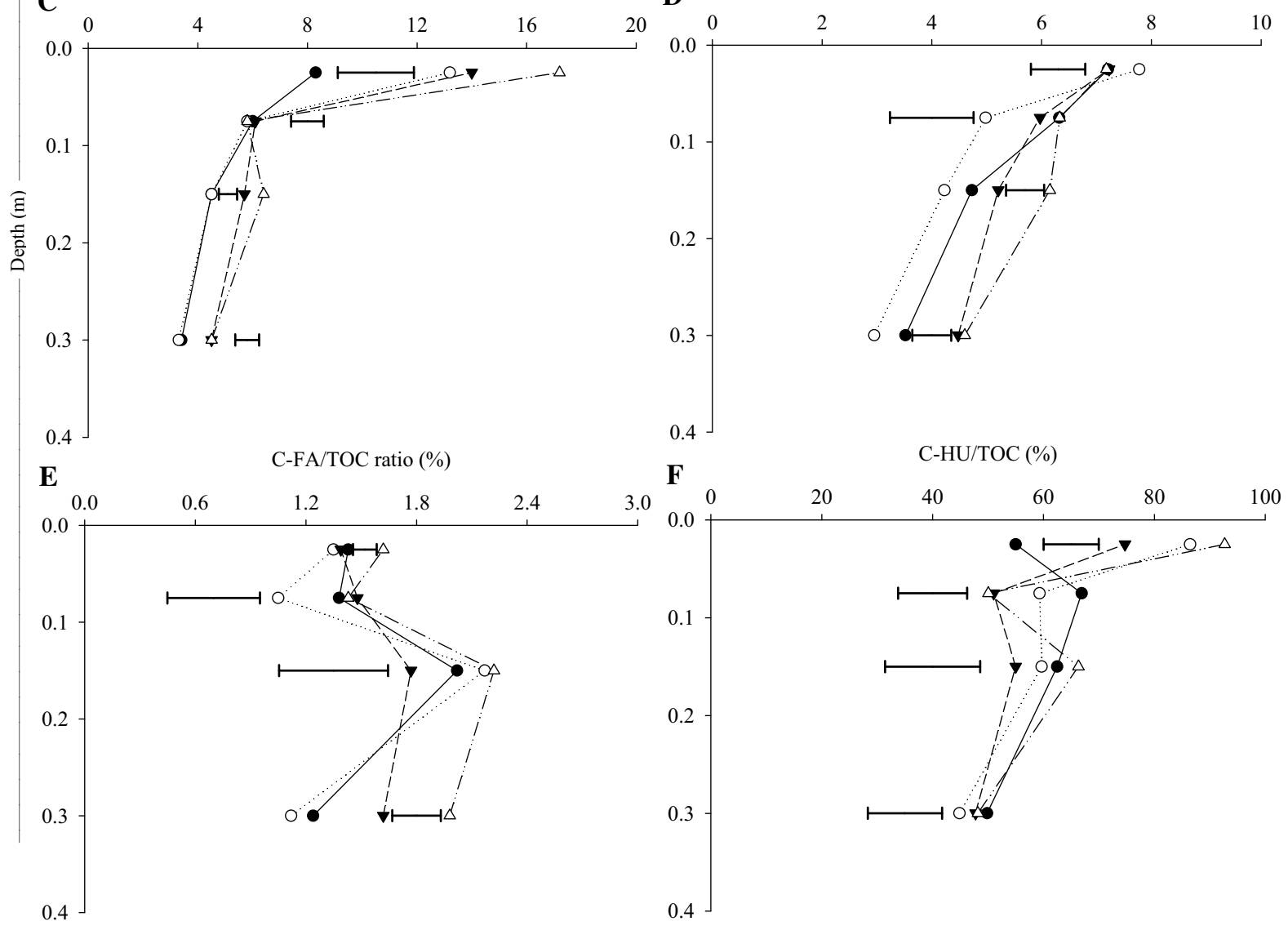

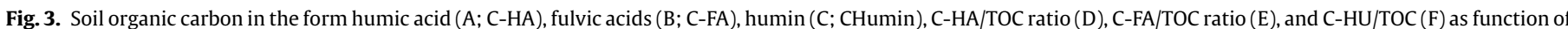

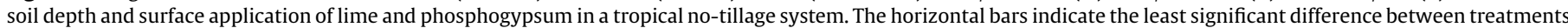
within each soil depth at $\mathrm{p} \leq 0.05$. TOC $=$ Total organic carbon. Lime and phosphogypsum applied in 2002, 2004 , and 2010.

that gypsum application improved microbial activity due to changes in soil chemistry and benefits related to root growth (via rhizodeposition), mainly during drought periods (Farina and Channon, 1988).

The effect of lime + phosphogypsum on increasing the mineralization rate is especially important considering the higher levels of $\mathrm{TN}$ in the 0 to $0.10-\mathrm{m}$ and 0.20 to $0.40-\mathrm{m}$ layers (Fig. 2B). According to Fuentes et al. (2006), lime-amended soil provided better environmental conditions for microbial growth, increasing the decomposition of the labile compounds 7.5 to 12.5 times that of non-limed soil, with less impact on decomposition at deeper soil depths. Because these labile compounds represent the main pathway of $\mathrm{N}$ into the soil, the TN levels in the soil vary according to the quantity of readily decomposable organic matter and microbial activity (Castro et al., 2015). The SOM particulate fraction is considered to be sensitive to soil conditions; thus, various practices, such as the application of lime + phosphogypsum, can change the $C$ input over long periods of time by influencing the decomposition rates of crop residues and $\mathrm{N}$ availability.

Regardless of phosphogypsum application, liming alone was a viable strategy to increase TOC in the soil profile (Fig. 2D); however, the POC/TOC ratio was lower compared to that observed 


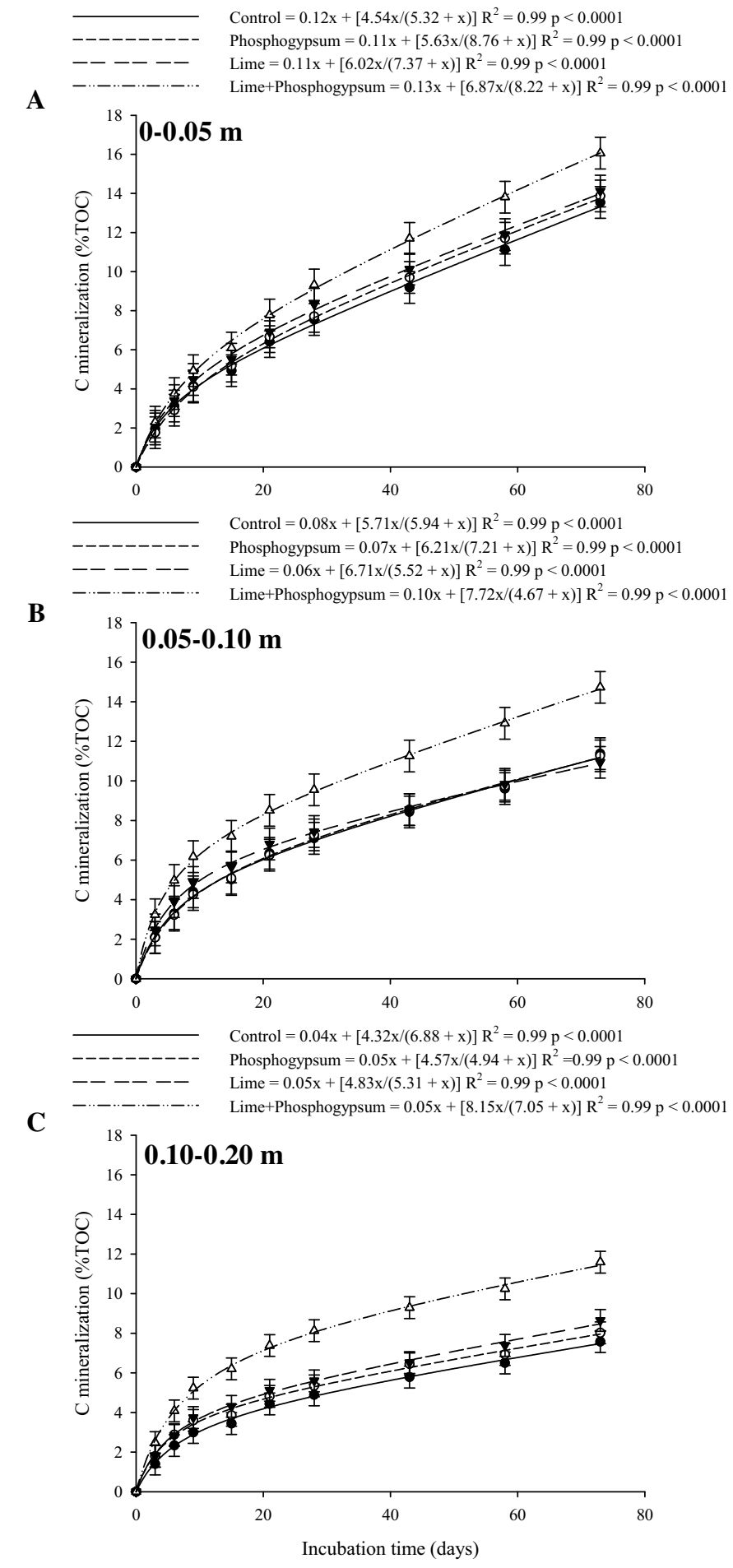

Fig. 4. Cumulative carbon mineralized at soil depths of $0-0.05 \mathrm{~m}(\mathrm{~A}), 0.05-0.10 \mathrm{~m}$ (B), and $0.10-0.20 \mathrm{~m}(\mathrm{C})$, as a function of surface application of lime and phosphogypsum in a tropical no-tillage system. The vertical bars indicate the least significant difference between treatments within each soil depth at $\mathrm{p} \leq 0.05$. Lime and phosphogypsum applied in 2002, 2004, and 2010.

following the application of both soil amendments in combination (Fig. 2F). Furthermore, liming alone increased the SOM pool (Fig. 2E) that was considered to be stable (MOC), which may be due to improved soil fertility (Briedis et al., 2012; Castro et al., 2015). Despite the lower correlation between exchangeable base cation availability and MOC compared with the correlation with other OC pools, base cations are generally believed to increase bonding between charged mineral surfaces and organic functional groups (Bronick and Lal, 2005). The effect of soil amendments on soil MOC may be related to $\mathrm{pH}$ changes. The soil acidification increases the solubility of $\mathrm{Fe}$ and $\mathrm{Al}$ in Oxisols, and according to Greenland (1971), the bond formed between metallic ions and carboxyl groups found in SOM tends to be very strong and have high stability, thereby increasing the interactions between mineral particles and organic molecules. Although gypsum is not an acidneutralizing material, the magnitude of acidification was lower in lime-amended soil treated with phosphogypsum ( $\mathrm{pH} 5.0$ ) compared with that in soil treated with lime alone ( $\mathrm{pH} \mathrm{4.5)}$ after 48 months from the last reapplication.

Several authors have reported that gypsum application in highly weathered and variably charged soils can release hydroxyl $\left(\mathrm{OH}^{-}\right)$through the specific adsorption of $\mathrm{SO}_{4}{ }^{2-}$, similar to the effects of phosphate $\left(\mathrm{PO}_{4}{ }^{2-}\right)$ application (Alva et al., 1990). Furthermore, as a consequence of higher root growth, the volume of explored soil is larger, and the contribution of alkaline ions, such as $\mathrm{HCO}_{3}{ }^{-}$and $\mathrm{OH}^{-}$, exuded by roots (Riley and Barber, 1969) may be increased with gypsum application due to the higher availability of anions in the soil solution, such as sulfate $\left(\mathrm{SO}_{4}{ }^{2-}\right)$ and nitrate $\left(\mathrm{NO}_{3}{ }^{-}\right)$. Crusciol et al. (2016) confirmed the ability of phosphogypsum to increase the levels of these anions in Oxisol soil solutions compared with the levels observed following the individual application of lime. Furthermore, Garbuio et al. (2011) emphasized that a higher input of plant residues can increase cation exchange surfaces and proton-bearing functional groups, which suggests a higher adsorption of $\mathrm{H}^{+}$and contributes to buffering the acidification process over time.

\subsection{Soil carbon mineralization, stability, and formation of humic substances}

The effect of lime + phosphogypsum on improving $C$ mineralization potentiality favors the decomposition of non-recalcitrant compounds, which can induce the synthesis of more stable molecules (i.e., humin and humic/fulvic acids) and improve the quality of SOM (Stevenson, 1994). Larger inputs of crop residues via aboveground residues and root fragments from the lime + phosphogypsum treatment accumulated over long periods of time and was associated with high mineralization rates, which could partially explain the development of resistant soil organo-mineral pools (Paradelo et al., 2015). Similarly, Clough and Skjemstad (2000) reported that this effect can be related to Ca-induced increases in the physical protection of these SOM pools. The researchers observed that various minerals, such as iron and aluminum oxides and hydroxides, found in a limed Oxisol were enriched with OC compared to their levels in unlimed soil. This result may be partly due to the interactions of polyvalent cations (such as $\mathrm{Ca}^{2+}$ from lime and phosphogypsum dissolution) with functional groups of minerals and organic matter. Such physical "protection" would constitute an important physio-chemical complex that reduces the loss of OC that normally occurs through microbial decomposition (Zech et al., 1997).

The large number of charged functional groups on humic substances $\left(3,000-14,200 \mathrm{mmol}_{\mathrm{c}} \mathrm{dm}^{-3}\right.$; Stevenson, 1994) provides the ideal conditions for the formation of chemical bonds with soil mineral particles for stabilizing humic compounds in tropical soils. Belkacem and Nys (1995) identified a significant correlation $\left(\mathrm{R}^{2}=0.72\right.$ ) between Ca and dissolved OC (such as HA and FA). This mechanism may explain the higher proportion of $\mathrm{OC}$ in the form of humic substances (C-HA/TOC, C-FA/TOC and C-HU/TOC ratios; Figs. $3 \mathrm{D}, 3 \mathrm{E}$ and $3 \mathrm{~F}$, respectively) in soils that received lime + phosphogypsum. In addition to the potential impact of Ca on OC stabilization, our results indicated significant correlations between other soil chemical properties and the amount of humic substances 
(Table 4), which may have had an impact on the stabilization and on the synthesis of these recalcitrant compounds, thereby affecting the OC quality. This may be an important strategy for increasing $\mathrm{C}$ storage in tropical soils, such as Oxisols.

The synergetic effect of phosphogypsum on increasing the amounts of C-FA and C-HU in the soil may also be related to others factors, such as the input of organic materials rich in lignin and phenolic polymers, which are considered the primary building blocks in humification (Ogner and Schnitzer, 1970). Oades (1988) demonstrated a positive correlation between organic compounds, such as lignin, and the amount and quality of organic residue inputs with the proportion of different plant parts that influence the composition of the organic substrate. Zech et al. (1997) suggested that the addition of materials rich in lignin, considered resistant to biological degradation, contributed to the synthesis of humic substances.

Oxidation and decarboxylation reactions, followed by microbiological action on lignin and others phenolic polymers, are also considered essential in the formation of humic substances. Soil acidity alleviation appears to increase the reactivity of some precursor compounds, such as tri-hydroxy phenols (Stott and Martin, 1990). According to Johnson et al. (2007), the amount of total lignin varies between plant species and plant parts within species. In the case of soybeans, the authors found that the leaves $\left(114 \mathrm{~g} \mathrm{~kg}^{-1}\right)$ and stems $\left(173 \mathrm{~g} \mathrm{~kg}^{-1}\right)$ had a lower concentration of total lignin than was found in the roots $\left(212 \mathrm{~g} \mathrm{~kg}^{-1}\right)$. Therefore, the influence of phosphogypsum on the C-HA/TOC, C-FA/TOC and C-HU/TOC ratios, as observed in our results (Fig. 3D-F), may also be related to root-residue lignin inputs due to improvements in the soil chemical conditions (Ogner and Schnitzer, 1970; Garbuio et al., 2011).

In general, as SOM accumulates at the soil surface, biological activity becomes more intense in this zone; consequently, more humic substances are synthesized and complexed with mineral particles (Clough and Skjemstad, 2000), which may explain the highest C-FA/TOC ratio observed in the 0 to $0.05 \mathrm{~m}$ layer. However, for humic substances not stabilized with minerals, the FA and HA may have leached downward in soils that received lime + phosphogypsum or lime alone due to the higher $\mathrm{pH}$ conditions at the surface (Stevenson, 1994). The leaching of FA and HA from the surface may explain the higher contribution of these compounds to TOC at the $0.10 \mathrm{~m}$ depth (Fig. 3D and E). However, the humin fraction, which is considered insoluble at all $\mathrm{pH}$ levels, did not appear to be impacted by the soil amendments below the $0.10 \mathrm{~m}$ depth (Fig. 3F).

The higher C-HU/TOC ratio in the $0-0.05$ and $0.05-0.10$-m layer in the phosphogypsum application and control treatment (Fig. 3F), respectively, may be related to the quality of substrate input (root and aboveground residues). This substrate provides low molecular weight compounds, such as polyphenols associated with $\mathrm{N}$ molecules, which are considered an important humification pathway for humin formation (Stevenson, 1994). In addition to the variation between plant species and plant parts within the species, as described above. Kraus et al. (2004) found that soil fertility and $\mathrm{pH}$ have a significant influence on secondary compounds synthesis, such as polyphenols and tannins, which are also considered important precursor molecules for humification. Therefore, soil acidity and low inputs of OC sources may reduce the synthesis of humin while increasing its stability. Grasset et al. (2002) suggested that humin is more resistant to biodegradation than HA and FA acids, due to its more complex structure. Similar to HA and FA, chemical bonds between humin, polyvalent ions and mineral particles may help to preserve humin. In this study, the low contribution of aboveground organic residues was also influenced by the low fertility of the control, and this combination may have increased the proportion of TOC as humin.
Although the phosphogypsum amended soil did not increase the MOC, this treatment was still able to increase the proportion of TOC in the form of HA and FA

\section{Conclusion}

Surface liming is considered an important tool for increasing the SOM input in tropical acid Oxisols under long-term NT systems. The maintenance of high concentrations of basic cations (such as $\mathrm{Ca}$ and $\mathrm{Mg}$ ) and low levels of exchangeable $\mathrm{Al}$ in the soil solution demonstrated a high correlation with the quantity and quality of SOM. Although phosphogypsum alone had no effect on the aboveground or root biomass, the combination with lime increased $\mathrm{N}$ availability and the formation and stabilization of humin, humic acid, and fulvic acid, increasing the proportion of $\mathrm{C}$ as humic substances. This impact on $C$ quality was attributed to soil chemical fertility improvements and the high input of organic residues. Therefore, the surface application of lime and phosphogypsum combined, which is associated with conservative practices (such as crop rotation and minimum reduced tillage), are considered key factors for improving the productivity capacity of Oxisols and consequently the sustainability of NT systems in tropical regions.

\section{Acknowledgments}

The authors would like to thank the São Paulo Research Foundation (FAPESP, Proc. 2013/18462-0 and 2014/16712-2). In addition, the third author would like to thank the National Council for Scientific and Technological Development (CNPq) for an award for excellence in research.

\section{References}

Alvarez, R., Alvarez, C.R., 2000. Soil organic matter pools and their associations with carbon mineralization kinetics. Soil Sci. Soc. Am. J. 64, 184-189.

Belkacem, S., Nys, C., 1995. Consequences of liming and gypsum top-dressing on nitrogen and carbon dynamics in acid forest soils with different humus forms. Plant Soil 173, 79-88.

Bernal, M.P., Sánchez-Monedero, M.A., Paredes, C., Roig, A., 1998. Carbon mineralization from organic wastes at different composting stages during their incubation with soil. Agric. Ecosyst. Environ. 69, 175-189.

Briedis, C., Sá, J.C.M., Caires, E.F., Navarro, J.F., Inagaki, T.M., Boer, A., Quadros Neto, C., Ferreira, A.O., Canalli, L.B., Santos, J.B., 2012. Soil organic matter pools and carbon-protection mechanisms in aggregate classes influenced by surface liming in a no-till system. Geoderma 170, 80-88.

Bronick, C.J., Lal, R., 2005. Soil structure and management: a review. Geoderma 124, $3-22$.

Caires, E.F., Barth, G., Garbuio, F.J., 2006. Lime application in the establishment of a no-till system for grain crop production in Southern Brazil. Soil Till. Res. 89, 3 12 .

Caires, E.F., Garbuio, F.J., Churka, S., Joris, H.A.W., 2011. Use of gypsum for crop grain production under a subtropical no-till cropping system. Agron. J. 103, 18041814.

Cambardella, C.A., Elliott, E.T., 1994. Carbon and nitrogen dynamics of soil organic matter fractions from cultivated grassland soils. Soil Sci. Soc. Am. J. 58, 123-130.

Cantarella, H., van Raij, B., Quaggio, J.A., 1998. Soil and plant analyses for lime and fertilizer recommendations in Brazil. Commun. Soil Sci. Plan. 29, 11-14.

Carter, M.R., 1986. Microbial biomass and mineralizable nitrogen in solonetzic soils: influence of gypsum and lime amendments. Soil Biol. Biochem. 18, 531-537.

Castro, G.S.A., Crusciol, C.A.C., Calonego, J.C., Rosolem, C.A., 2015. Management impacts on soil organic matter of tropical soils. Vadose Zone J. 1, 0-8.

Ciavatta, C., Govi, M., Vittori Antisari, L., Sequi, P., 1990. Characterization of humified compounds by extraction and fractionation on solid polyvinylpyrrolidone. J. Chromatogr. 509, 141-146.

Clough, A., Skjemstad, J.O., 2000. Physical and chemical protection of soil organic carbon in three agricultural soils with different contents of calcium carbonate. Aust. J. Soil Res. 38, 1005-1016.

Crusciol, C.A.C., Artigiani, A.C.C.A., Arf, O., Carmeis Filho, A.C.A., Soratto, R.P., Nascente, A.S., Alvarez, R.C.F., 2016. Soil fertility, plant nutrition, and grain yield of upland rice affected by surface application of lime, silicate, and phosphogypsum in a tropical no-till system. Catena 137, 87-99.

Fageria, N.K., Moreira, A., 2011. The role of mineral nutrition on root growth of crop plants. Adv. Agron. 110, 251-331.

Fageria, N.K., Nascente, A.S., 2014. Management of soil acidity of south american soils for sustainable crop production. Adv. Agron. 128, 221-275. 
Farias, E.P., Zonta, E., Canellas, L.P., Santos, G.A., 2005. Input of dissolved carbon and its influence on humic substances content in an Oxisol. (in Portuguese with English abstract). R. Bras. Ci. Solo 29, 875-882.

Farina, M.P.W., Channon, P., 1988. Acid-subsoil amelioration: ii. Gypsum effects on growth and subsoil chemical properties. Soil Sci. Soc. Am. J. 52, 175-180.

Feller, C., Beare, M.H., 1997. Physical control of soil organic matter in the tropics. Geoderma 79, 69-116.

Fuentes, J.P., Bezdicek, D.F., Flury, M., Albrecht, S., Smith, J.L., 2006. Microbial activity affected by lime in a long-term no-till soil. Soil Tillage Res. 88, 123-131.

Garbuio, F.J., Jones, D.L., Alleoni, L.R.F., Murphy, D.V., Caires, E.F., 2011. Carbon and nitrogen dynamics in an oxisol as affected by liming and crop residues under no-till. Soil Sci. Soc. Am. J. 75, 1723-1730.

Grasset, L., Guignard, C., Amblès, A., 2002. Free and esterified aliphatic carboxylic acids in humin and humic acids a peat sample as revealed by pyrolysis with tetramethylammonium hydroxide or tetrathylammonium acetate. Org. Geochem. 33, 181-188.

Greenland, D.J., 1971. Interactions between humic and fulvic acids and clays. Soil Sci. $111,34-41$.

Haynes, R.J., Naidu, R., 1998. Influence of lime, fertilizer and manure applications on soil organic matter content and soil physical conditions: a review. Nutr. Cycl. Agroecosys. 51, 123-137.

Heanes, D.L., 1984. Determination of total organic-C in soils by an improved chromic acid digestion and spectrophotometric procedure. Commun. Soil Sci. Plant Anal. $10,1191-1213$.

Illés, E. Tombácz, E. 2006. The effect of humic acid adsorption on pH-dependent surface charging and aggregation of magnetite nanoparticles. J. Colloid Interface Sci. 295, 115-123.

Johnson, J.M.F., Barbour, N.W., Weyers, S.L., 2007. Chemical composition of crop biomass impacts its decomposition. Soil Sci. Soc. Am. J. 71, 155-162.

Kraus, T.E.C., Zasoski, R.J., Dahlgren, R.A., 2004. Fertility and pH effects on polyphenol and condensed tannin concentrations in foliage and roots. Plant Soil 262, 95-109.

Meda, A.R., Pavan, M.A., Cassiolato, M.E., Miyazawa, M., 2002. Dolomitic limestone's reaction applied on the surface of a sandy soil of the northwest Paraná. Brasil. Braz. Arch. Bio. Tech. 45, 219-222.

Murphy, J., Riley, J.P., 1962. A modified single solution method for the determination of phosphate in natural waters. Anal. Chim. Acta 27, 31-36. doi:http://dx.doi. org/10.1016/S0003-2670(00)88444-5.

Oades, J.M., 1988. The retention of organic matter in soils. Biogeochemistry 5, 35-70.

Oates, K.M., Calswell, A.G., 1985. Use of by-product gypsum to alleviate soil acidity. Soil Sci. Soc. Am. J. 49, 915-918.

Ogner, G., Schnitzer, M., 1970. Chemistry of fulvic acid, a soil humic fraction, and its relation to lignin. Can. J. Chem. 49, 1053-1063.
Oussible, M., Crookston, R.K., Larson, W.E., 1992. Subsurface compaction reduces the root and shoot growth and grain yield of wheat. Agron. J. 84, 34-38.

Paradelo, R., Virto, I., Chenu, C., 2015. Net effect of liming on soil organic carbon stocks. A review. Agric. Ecosyst. Environ. 202, 98-107.

Rheinheimer, D.S., Campos, B.C., Giacomoni, S.J., Conceição, P.C., Bortoluzzi, E.C., 2008. Comparação de métodos de determinação de carbono orgânico total no solo (in Portuguese with English abstract). R. Bras. Ci. Solo 32, 435-440.

Riley, D., Barber, S.A., 1969. Bicarbonate accumulation and pH changes at soybean (Glycine $\max$ (L.) Merr.) root-aoil interface. Soil Sci. Soc. Am. Proc. 33, 905-908.

Soratto, R.P., Crusciol, C.A.C., 2008. Dolomite and phosphophosphogypsum surface application effects on annual crops nutrition and yield. Agron. J. 100, 261-270. doi:http://dx.doi.org/10.2134/agrojnl2007.0120.

Sposito, G., 2008. The Chemistry of Soils, second ed. Oxford University, New York 330p.

Stevenson, F.J., 1994. Humus Chemistry: Genesis, Composition, Reactions, second ed. John Willey, New York 496p.

Stott, D.E., Martin, J.P., 1990. Synthesis and degredation of natural and synthetic humic material in soils. In: MacCarthy, P., Clapp, C.E., Malcolm, R.L., Bloom, P.R (Eds.), Humic Substances in Soil and Crop Sciences: Selected Readings'. Americal Society of Agronomy Inc., Madison, pp. 37-64.

Sumner, M.E., Shahandeh, J., Bouton, J., Hammel, J., 1986. Amelioration of an acid soil profile through deep liming and surface application of gypsum. Soil Sci. Soc. Am. Proc. 36, 587-593.

USDA, United States Department of Agriculture, 1999. Soil Taxonomy: a basic system of soil classification for making and interpreting soil surveys. 2nd ed. USDA NRCS, Agriculture Handbook, Washington DC. $<$ https://www.nrcs.usda.gov/ Internet/FSE_DOCUMENTS/nrcs142p2_051232.pdf>(Accessed 7 July 2015).

van Raij, B., Quaggio, J.A., Silva, N.M., 1986. Extraction of phosphorus, potassium, calcium, and magnesium from soils by an ion-exchange resin procedure. Commun. Soil Sci. Plan. 17, 547-566.

van Raij, B., Andrade, J.C., Cantarella, H., Quaggio, J.A., 2001. Chemical Analysis for Fertility Evaluation of Tropical Soils (in Portuguese). Instituto Agronômico (IAC), Campinas, Brazil.

Von Uexkuell, H.R., Mutert, E., 1995. Global extent, development and economic impact of acid soils. Plant Soil 171, 1-15.

Wang, H.C., Chou, C.Y., Chiou, C.R., Tian, G., Chiu, C.Y., 2016. Humic acid composition and characteristics of soil organic matter in relation to the elevation gradient of moso bamboo plantations. PLoS One 11 (9), e0162193.

Weir, R.G., Barkus, B., Atkinson, W.T., 1963. The effect of particle size on the availability of brimstone sulphur to white clover. Aust. J. Exp. Agr. Anim. Husb. 3, 314-318.

Zech, W., Senesi, N., Guggenberger, G., Kaiser, K., Lehmann, J., Miano, T.M., Miltner A., Schroth, G., 1997. Factors controlling humification and mineralization of soil organic matter in the tropics. Geoderma 79, 117-161. 